\title{
Vertical Water Velocity Distribution Using Fine Different Sediment Concentrations in Circular Open Channel
}

\author{
Mohamed Gamal Mohamed Abdalla \\ Irrigation and Hydraulics Dept., Faculty of Engineering, Mansoura University, Mansoura, Egypt \\ Email address: \\ mgmabdalla3@yahoo.com \\ To cite this article: \\ Mohamed Gamal Mohamed Abdalla. Vertical Water Velocity Distribution Using Fine Different Sediment Concentrations in Circular Open \\ Channel. Journal of Water Resources and Ocean Science. Vol. 5, No. 6, 2016, pp. 93-103. doi: 10.11648/j.wros.20160506.13
}

Received: October 22, 2016; Accepted: November 1, 2016; Published: December 16, 2016

\begin{abstract}
The effect of fine different sediment concentrations on velocity distribution in open circular pipe was experimentally studied. An "ADV"(Acoustic Doppler Velocimeter) instrument was used for measuring the velocity distribution at the centerline of channel. Three different sediment concentrations of $1000 \mathrm{gm}, 1500 \mathrm{gm}$ and $2000 \mathrm{gm}$ were added to the input upstream tank of the used channel with dimensions of $67.5 \mathrm{~cm} \times 154 \mathrm{~cm} \times 25 \mathrm{~cm}\left(0.26 \mathrm{~m}^{3}\right)$. To find out separately the final concentrations of suspended load and bed load, a trap was designed at the end of the channel. Three water depths were used $11 \mathrm{~cm}, 13 \mathrm{~cm}$ and $15 \mathrm{~cm}$ to give depth-diameter ratios of 0.55, 0.65 and 0.75 . A maximum discharge of 1.50 lit. / $/ \mathrm{sec}$ was used. From this experimental research the time of each run that used to separate between bed and suspended loads was three hours. After that, (after three hours from starting run), the "ADV" instrument was used to measure the distribution of water velocity. The run was repeated for all total load sediment concentrations and for the three depth-diameter ratios mentioned before to separate the bed load and suspended load. From the analysis, it was concluded that with the increasing of suspended load, the water velocity decreases obviously. The increasing of water depth causes the increase of bed load and the decrease in suspended load concentrations. Different polynomial equations were deduced, at the centerline only, to study the effect of run time and water depth-diameter ratio on bed load quantity by weight.
\end{abstract}

Keywords: Bed Load, Suspended Load, Circular Channel, ADV Instrument, Velocity Distribution

\section{Introduction}

Moving sediments in several parts of flow is considered the main item for used formulas that calculate sediment transport rate. These formulas are often separated into bed load, suspended, and wash load.

Bed load moves in the lower part of the channel or river in form of rolling, sliding with bed or in saltating over the bed.

Suspended load usually found in the lower to middle parts of the flow, and moves with the flow velocity in the stream.

The oldest known sediment transport study was done around 4000 years ago in China [1].

A significant work has been done in the last century in the field of sediment transport. All studies could be classified into physical studies and mathematical studies.

Physical studies are done by doing experiments in laboratory flumes or by taking field observations.

Laboratory studies are not well representative of the river system as it is difficult to represent a river by a laboratory flume. So a lot of assumptions are usually incorporated in laboratory studies. Still these laboratory studies are important for verification of other studies and also to understand basic concepts of river flow and sediment transport. One of the oldest and still widely used studies was done by Newton [10]. Also, Suryanarayana and Shen [15] did extensive laboratory flume studies for three different sediment particle sizes using uniform sediment grain size for each experimental run.

The vertical distribution of water velocity with suspended sediment concentration has been investigated in turbulent flow by many researchers.

The problems of sediment-laden flows are important to river engineers and geomorphologists. This problem related to the field such as coastal sediment transport and transport of solids in pipelines.

Studying the vertical distribution of sediment concentration with water velocity is based on the logarithmic velocity distribution given by Prandtl mixing-length 
hypothesis and on von-Karman similarity hypothesis (Schlichting and Gersten, [14]).

The vertical water velocity profile is described by a 'loglaw' in case of flow over smooth bed in open channels without moving sediment. Through the measurements in the whole turbulent boundary layer zone, the 'log-law' could be only applied to the near wall region with the von Karman constant $\kappa$ equals 0.4 and the integrating constant could be 5.29 .

Coles [2] developed a semi-empirical equation that modifies the 'log-law' based on wake-strength function. This developed equation could be applied to the whole turbulent boundary layer zone.

Several researchers Coles [2], Nezu and Rodi [11] and Nezu and Nakagawa [12] used 'wake-function' to account the deviation from the "log-law" and they recommended that the measured water velocity cannot be fitted only by log-law.

Vanoni [17] and Einstein and Chien [4] found that a smaller value of " $k$ " than the universal one $(k=0.4)$ gave an excellent results with their experimental results of velocity and suspension distributions except the zone near bottom. They concluded that, the von-Karman coefficient $\kappa$ reduced with the increase in suspension concentration.

New models for velocity distribution were made by Itakura and Kishi [6] and Coleman [3] to concentration of vertical sediments using constant value of " $k$ ".

Thacker and Lavelle [7] explained the effects of hindered settling on the concentrations of vertical sediment profiles. Also, Woo et al. [16] estimated the vertical concentration of particles "sand particles" using the log law and power law based on the hindered settling effects.

Mazumder and Ghoshal [8] proposed a new theoretical model for vertical sediment and velocity concentration profiles using fine, medium and coarse sediment.

Pellachini [13] provided a new relationship for the bed load transport of the sand fraction when gravel particles remain at rest.

Milad et al. [9] provided a study to set up a physical model based on the key variables in the previous transport equation to study the transport process in shallow grade culverts and storm sewers.

The mechanics of sediment transport is important for civil and hydraulics engineering structures such as culverts, dams, and around bridge piers as the resulted erosion of the bed. This erosion can damage the environment and expose or unsettle the foundations of the structure. (Grant et al., [5]). So, in this paper, studying the effect of different fine sediment concentrations on the vertical velocity profiles in circular pipe was experimentally studied using "ADV" (Acoustic Doppler Velocimeter) instrument. Also, the bed load was separated from the total load by a trap and the effect of time on the settling process was studied. New relationships between vertical velocity and suspended load concentration were also deduced.

\section{Experimental Work}

All tests were exerted in a circular tilting flume of $20 \mathrm{~cm}$ diameter, and $5.0 \mathrm{~m}$ long, figure 1 , in irrigation and hydraulics laboratory in Mansoura University.

Figures (2, 3 and 4) show the flume, plan and its side view and input tank with a specified water volume of $67.5 \mathrm{~cm} \times$ $154 \mathrm{~cm} \times 25 \mathrm{~cm}$ to give constant water volume of $0.26 \mathrm{~m}^{3}$. This input tank used for mixing all used sediment concentrations.

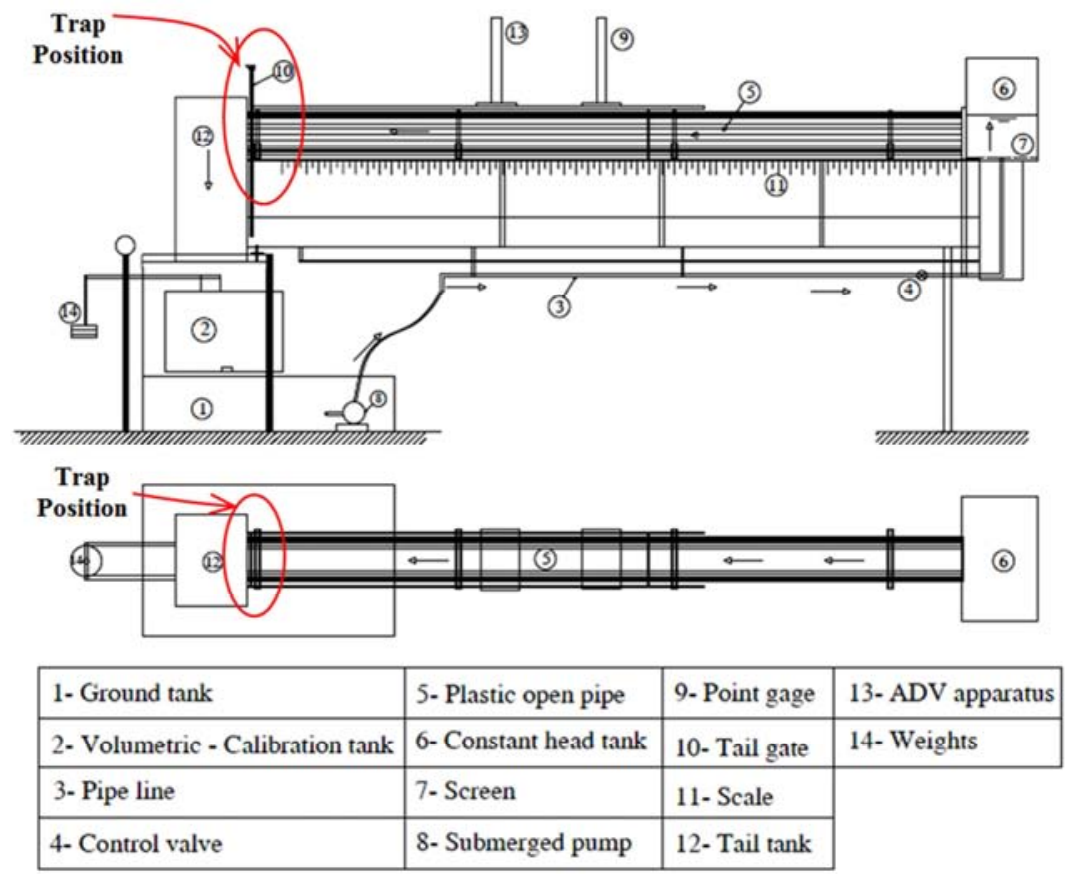

Figure 1. Elevation and plan of the used flume. 


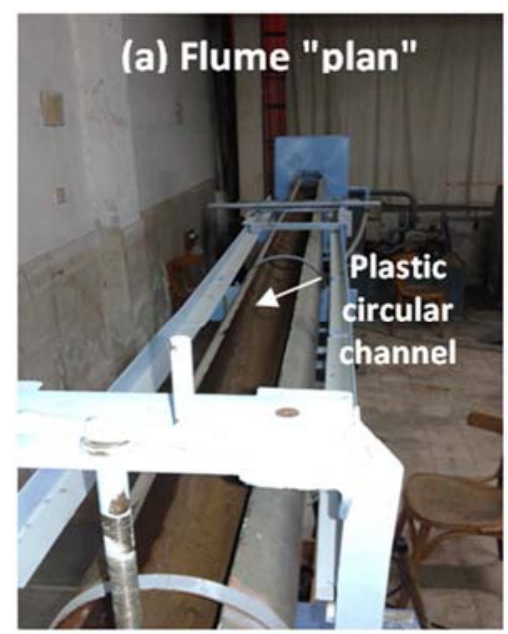

Figure 2. Flume "plan".

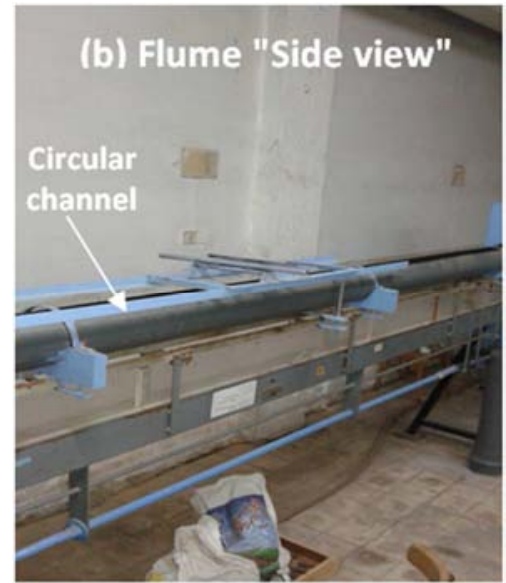

Figure 3. Flume "side view".

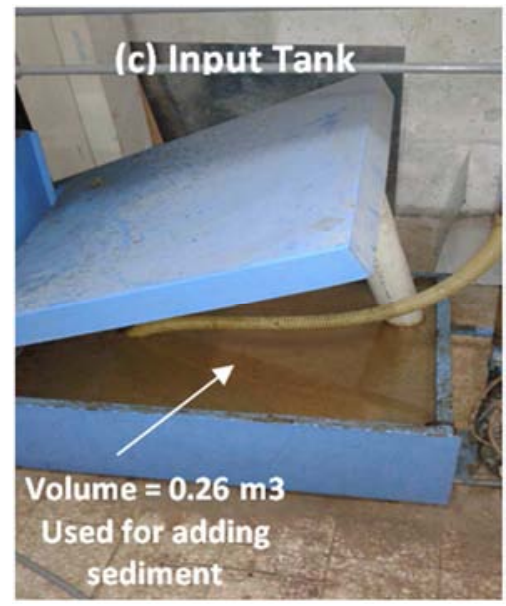

Figure 4. Input tank with $0.26 \mathrm{~m}^{3}$.

First, three runs were exerted for measuring water velocity distribution without any sediments (pure water) using ADV instrument at water depths of $11 \mathrm{~cm}(\mathrm{~h} / \mathrm{D}=0.55), 13 \mathrm{~cm}(\mathrm{~h} / \mathrm{D}$ $=0.65)$ and $15 \mathrm{~cm}(\mathrm{~h} / \mathrm{D}=0.75)$ with a discharge of 1.5 lit. /sec. as a maximum discharge could be obtained in the used flume.
In which, $\mathrm{h}=$ water depth measured at the centerline of channel and $\mathrm{D}=$ diameter of used channel, equals $20 \mathrm{~cm}$. After that, three different sediment concentrations, represents the values of total load, of $1000 \mathrm{gm}, 1500 \mathrm{gm}$ and $2000 \mathrm{gm}$ were prepared from fine clay soil with average geometric mean size of $\mathrm{d}_{50}=0.097 \mathrm{~mm}$. Then, for each concentration, three runs were exerted for the selected thee water depths.

Through the run time, the quantity of bed load was estimated with time propagation by weight (gm) at the trap used at the end of channel. The rate of increasing bed load with run time is the same rate of increasing suspended load. The run time was estimated to be 3.0 "three" hours.

After three hours from starting run, the concentration of suspended load remains constant and then, the "ADV" instrument, figure 5 and figure 6 , with accuracy equals $1 \%$ of measured velocity and resolution of $0.01 \mathrm{~cm} / \mathrm{sec}$., was used for measuring water velocity distribution.
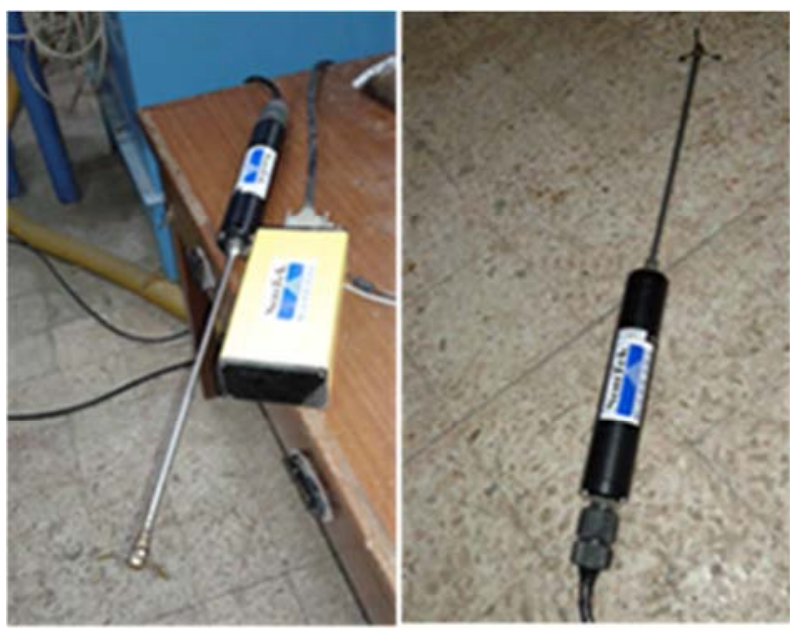

Figure 5. Acoustic Doppler Velocimeter.

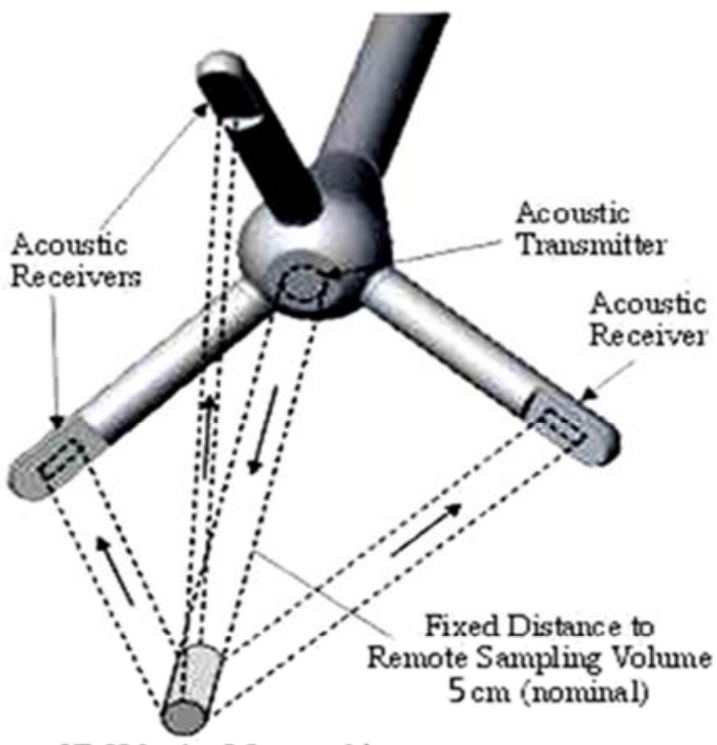

3D Velocity Measued in

Remote Sampling Volume Diameter $0.4 \mathrm{~cm}$, Height $0.45 \mathrm{~cm}$

Figure 6. Sketch of measuring a sample. 
Acoustic Doppler Velocimeter Instrument

Sensor mounted on a $25 \mathrm{~cm}$ stem.

High sampling rates: up to $50 \mathrm{~Hz}$.

Small sampling volume: less than $0.1 \mathrm{~cm} 3$

Accuracy: $1 \%$ of measured range

Range of velocity: $1 \mathrm{~mm} / \mathrm{s}$ to $2.5 \mathrm{~m} / \mathrm{s}$

Low-flow performance: excellent

No recalibration needed.

\section{Sedimentation Rates with Time Propagation}

To explain the change of suspended sediment concentration in water with time, the sediment particles was collected in the trap zone at the end of the channel after 0.5 hr., $1.0 \mathrm{hr}$., $2 \mathrm{hrs}$. and $3 \mathrm{hrs}$. from starting run. Then, the quantity of suspended load that moves with water equals the difference between total load added and the collected quantity of bed load. Figures 7 through 9 explain the variation of bed and suspended load with time at different total load concentrations.
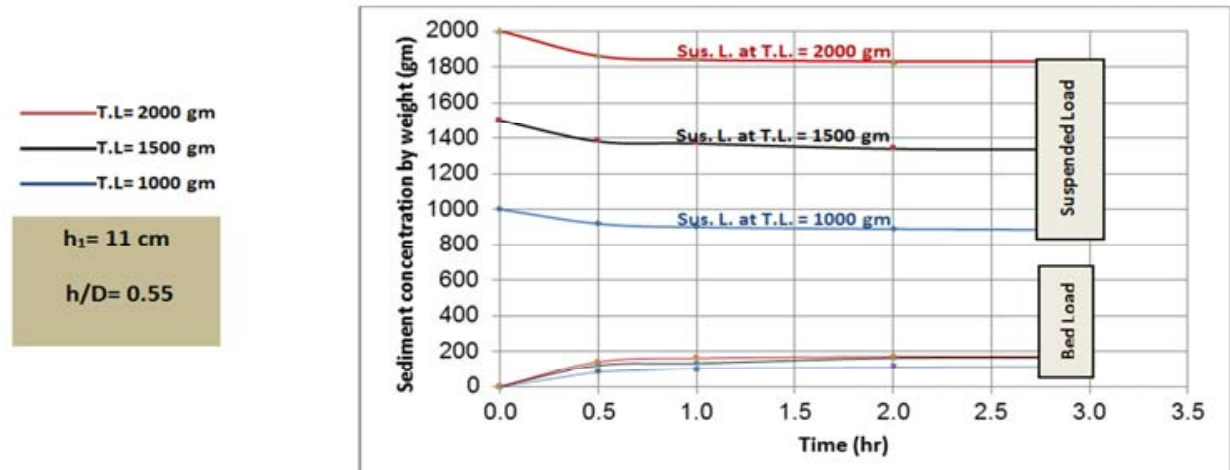

Figure 7. Bed and suspended load variation with time at water depth-diameter ratio $h / D=0.55$.

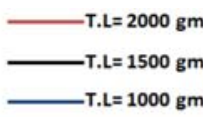

$h_{1}=11 \mathrm{~cm}$
$h / D=0.65$

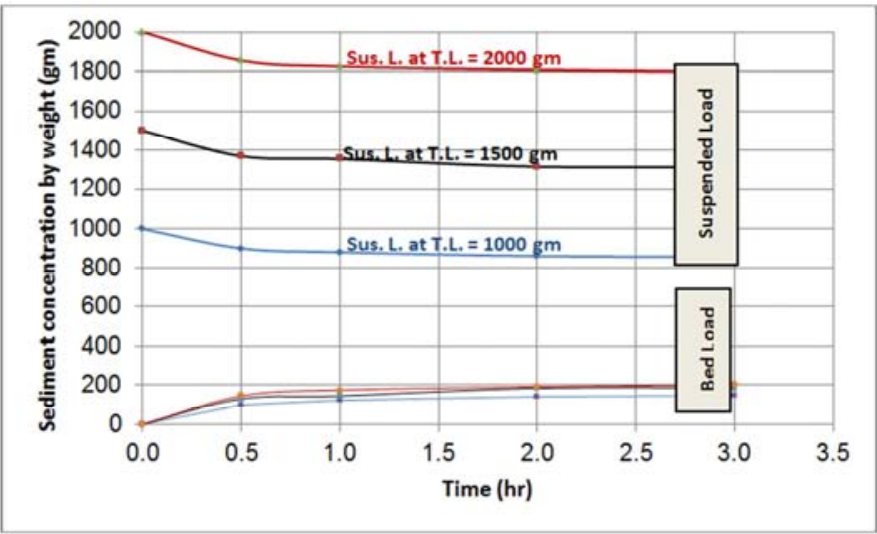

Figure 8. Bed and suspended load variation with time at water depth-diameter ratio $h / D=0.65$.
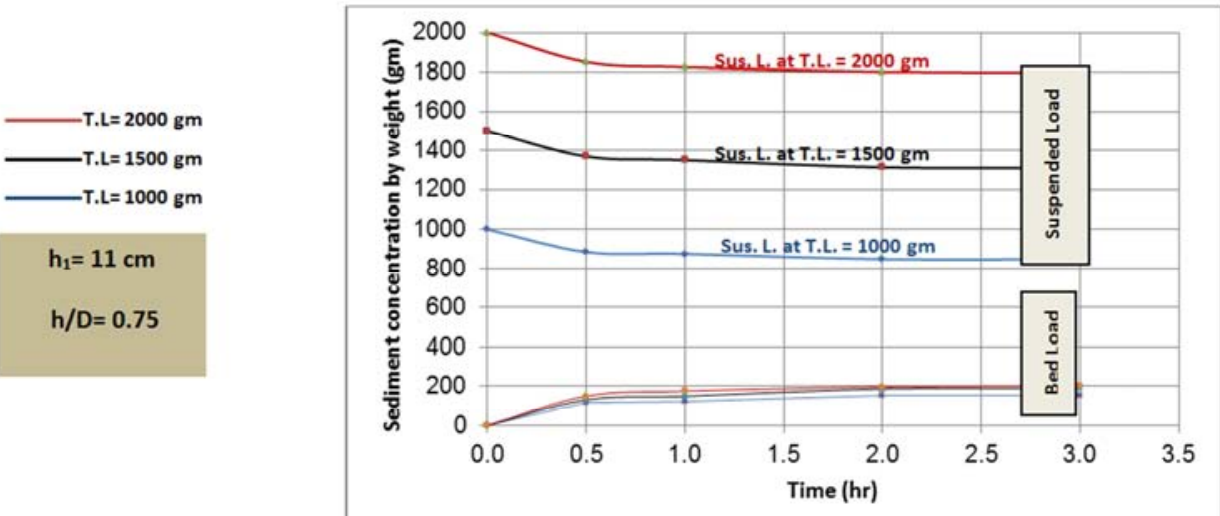

Figure 9. Bed and suspended load variation with time at water depth-diameter ratio $h / D=0.75$. 
The rate of increasing bed load with time for different total loads concentrations at the three used water depth-diameter ratios was explained through the following third degree polynomial equations.

- Total load $=1000 \mathrm{gm}$

$$
\begin{aligned}
& \mathrm{q}(\mathrm{gm})= 18.81 \mathrm{t}^{3}-109.41 \mathrm{t}^{2}+197.41 \mathrm{t} \\
& \mathrm{R}^{2}=0.99, \text { ath } / \mathrm{D}=0.55 \\
& \mathrm{q}(\mathrm{gm})=21.29 \mathrm{t}^{3}-126.11 \mathrm{t}^{2}+235.33 \mathrm{t} \\
& \mathrm{R}^{2}=0.98 \text { at } \mathrm{h} / \mathrm{D}=0.65 \\
& \mathrm{q}(\mathrm{gm})=23.32 \mathrm{t}^{3}-138.75 \mathrm{t}^{2}+257.38 \mathrm{t} \\
& \mathrm{R}^{2}=0.96, \text { at } \mathrm{h} / \mathrm{D}=0.75
\end{aligned}
$$

- Total load $=1500 \mathrm{gm}$

$$
\begin{gathered}
\mathrm{q}(\mathrm{gm})=24.23 \mathrm{t}^{3}-143.88 \mathrm{t}^{2}+269 \mathrm{t} \\
\mathrm{R}^{2}=0.96, \text { at } \mathrm{h} / \mathrm{D}=0.55 \\
\mathrm{q}(\mathrm{gm})=23.92 \mathrm{t}^{3}-146.47 \mathrm{t}^{2}+286 \mathrm{t} \\
\mathrm{R}^{2}=0.96 \text { at } \mathrm{h} / \mathrm{D}=0.65
\end{gathered}
$$

$$
\begin{gathered}
\mathrm{q}(\mathrm{gm})=25.02 \mathrm{t}^{3}-151.95 \mathrm{t}^{2}+295 \mathrm{t} \\
\mathrm{R}^{2}=0.97, \mathrm{~h} / \mathrm{D}=0.75
\end{gathered}
$$

- Total load $=2000 \mathrm{gm}$

$$
\begin{array}{r}
\mathrm{q}(\mathrm{gm})=33.96 \mathrm{t}^{3}-195.3 \mathrm{t}^{2}+337.31 \mathrm{t} \\
\mathrm{R}^{2}=0.97, \text { at } \mathrm{h} / \mathrm{D}=0.55 \\
\mathrm{q}(\mathrm{gm})=34.25 \mathrm{t}^{3}-197.4 \mathrm{t}^{2}+351.54 \mathrm{t} \\
\mathrm{R}^{2}=0.99, \text { at } \mathrm{h} / \mathrm{D}=0.65 \\
\mathrm{q}(\mathrm{gm})=33.80 \mathrm{t}^{3}-197.3 \mathrm{t}^{2}+355.67 \mathrm{t} \\
\mathrm{R}^{2}=0.97, \text { at } \mathrm{h} / \mathrm{D}=0.75
\end{array}
$$

\begin{tabular}{|c|c|c|c|c|c|c|c|}
\hline \multicolumn{4}{|c|}{ T.L. $=1000(\mathrm{gm})$} & \multicolumn{2}{|c|}{ T.L. $=1500(\mathrm{gm})$} & \multicolumn{2}{|c|}{ T.L. $=2000(\mathrm{gm})$} \\
\hline h/D & h (cm) & B.L. (gm) & ${ }^{*}$ Sus. L. $\left(\mathrm{kg} / \mathrm{m}^{3}\right)$ & B.L. (gm) & Sus. L. $\left(\mathrm{kg} / \mathrm{m}^{3}\right)$ & B.L. (gm) & Sus. L. $\left(\mathrm{kg} / \mathrm{m}^{3}\right)$ \\
\hline 0.55 & 11 & 115 & 3.40 & 165 & 5.13 & 170 & 7.04 \\
\hline 0.65 & 13 & 145 & 3.28 & 186 & 5.05 & 202 & 6.92 \\
\hline 0.75 & 15 & 152 & 3.26 & 190 & 5.03 & 203 & 6.91 \\
\hline
\end{tabular}

In which, $\mathrm{q}=$ bed load (gm) and $\mathrm{t}=$ time by hour.

The aforementioned equations could be applied only at the discharge of 1.5 lit./sec. and for circular pipe channel, at the centerline, with $\mathrm{h} / \mathrm{D}$ ratios ranged from 0.55 to 0.75 .

The final quantities of bed load and the corresponding suspended load sediments after three hours from starting operating were concluded in the following table.

Table (1) presents the final values of bed load and the corresponding suspended load at different total loads.

Table 1. Final values of bed load and the corresponding bed load at different total loads.

Suspended load concentration was calculated in the aforementioned table as:-

\section{- Example:}

-If the used total load equals $1000 \mathrm{gm}$, bed load trapped at the final run time is $115 \mathrm{gm}$ and the dimensions of input tank equal $67.5 \mathrm{~cm} \times 154 \mathrm{~cm} \times 25 \mathrm{~cm}\left(0.26 \mathrm{~m}^{3}\right)$. Then, Suspended load concentration $=(1000-115) /(0.26 \times 1000)=3.40$ $\mathrm{kg} / \mathrm{m}^{3}$.

\section{Velocity Distribution}

Vertical velocity distribution at the final obtained different suspended load concentrations given in table (1) for the three selected water depth-diameter ratio $\mathrm{h} / \mathrm{D}=0.55,0.65$ and 0.75 were presented in figures 10 through 12 .

In these figures the concentration of suspended load sediments affects obviously the water velocity.

Then, three final equations were deduced to associate between the concentration of suspended load by $\left(\mathrm{kg} / \mathrm{m}^{3}\right)$ and the mean water velocity measured by ADV instrument by (cm/sec.).
These equations are polynomial functions from the second degree and must be applied only for circular channel and discharge of 1.5 lit. /sec. at the centerline.

$$
\begin{aligned}
\mathrm{V}_{\mathrm{m}}(\mathrm{cm} / \mathrm{sec} .) & =0.0167 \mathrm{C}^{2}-0.2702 \mathrm{C}+8.6273 \\
\mathrm{R}^{2}= & 0.9993 \text { at }[\mathrm{h} / \mathrm{D}=0.55] \\
\mathrm{V}_{\mathrm{m}}(\mathrm{cm} / \mathrm{sec} .) & =0.0211 \mathrm{C}^{2}-0.3257 \mathrm{C}+9.0092 \\
\mathrm{R}^{2}= & 0.9993 \mathrm{at}[\mathrm{h} / \mathrm{D}=0.65] \\
\mathrm{V}_{\mathrm{m}}(\mathrm{cm} / \mathrm{sec} .) & =0.0564 \mathrm{C}^{2}-0.7303 \mathrm{C}+8.708 \\
\mathrm{R}^{2}= & 0.996 \mathrm{at}[\mathrm{h} / \mathrm{D}=0.75]
\end{aligned}
$$

In which,

$\mathrm{V}_{\mathrm{m}}=$ mean velocity at the section by $\mathrm{cm} / \mathrm{sec}$., and $\mathrm{C}=$ concentration of suspended load by $\mathrm{kg} / \mathrm{m}^{3}$. 

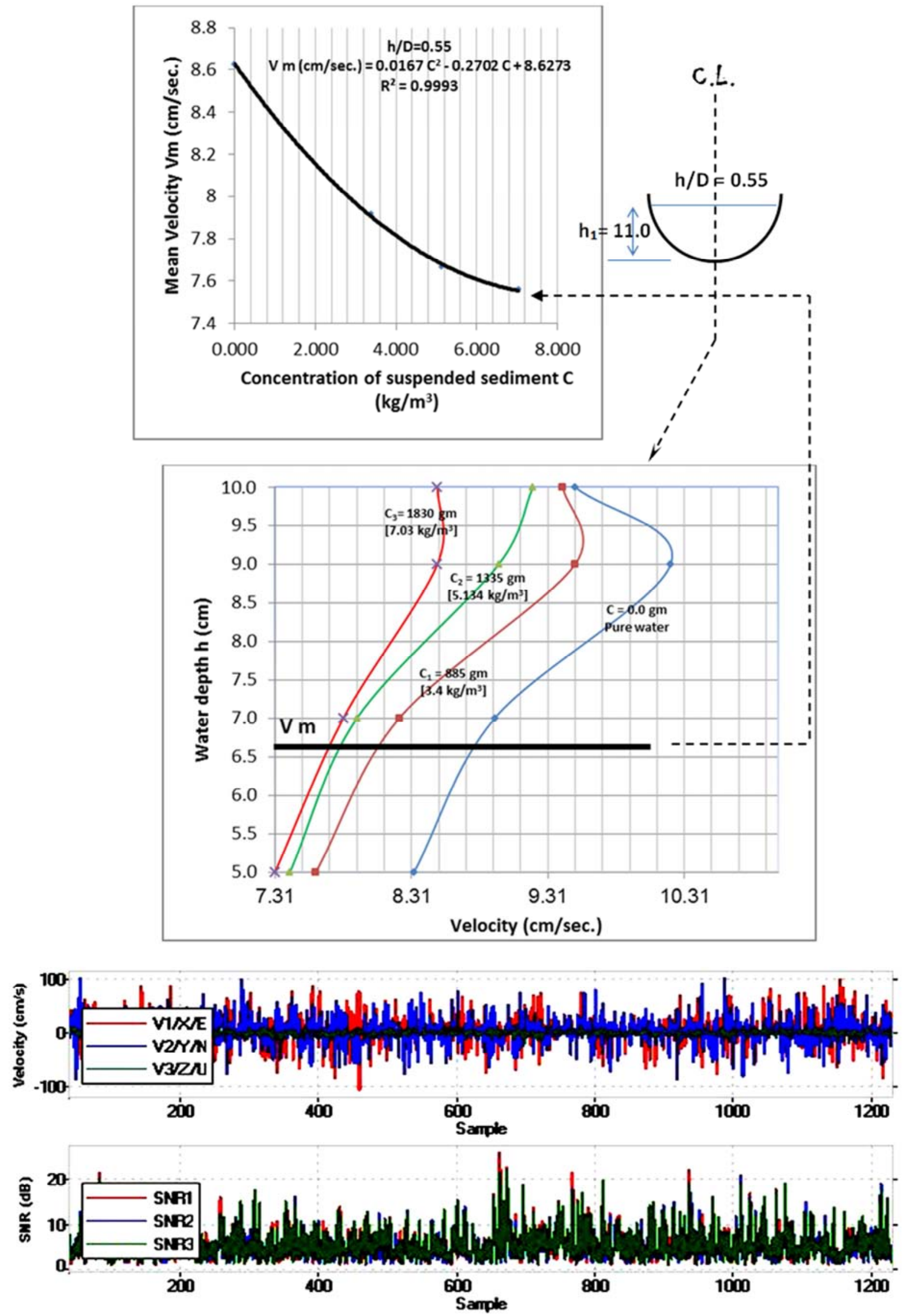

Figure 10. Velocity distribution at for final suspended load concentrations at $[h / D=0.55]$. 

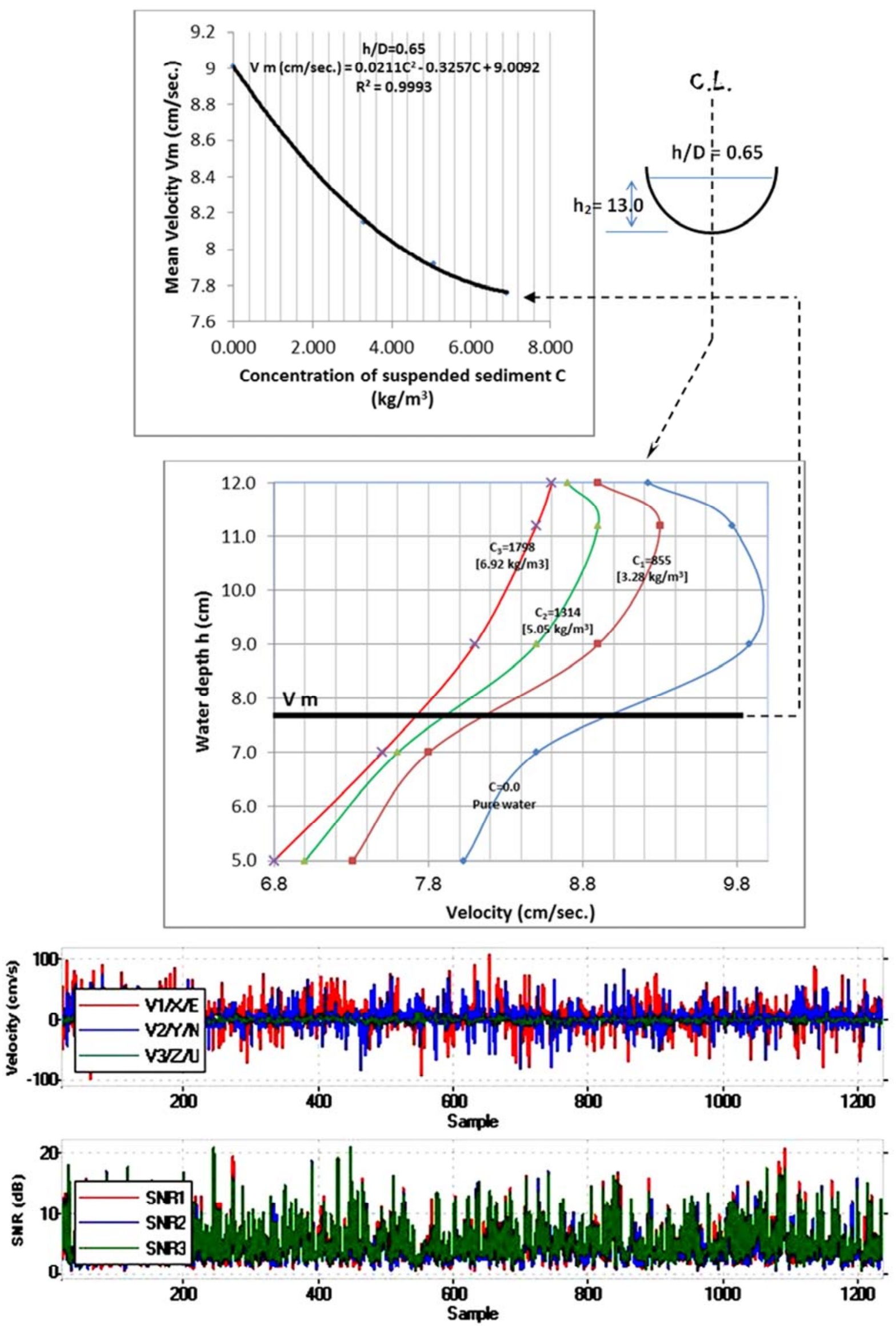

Figure 11. Velocity distribution at for final suspended load concentrations at $[h / D=0.65]$. 

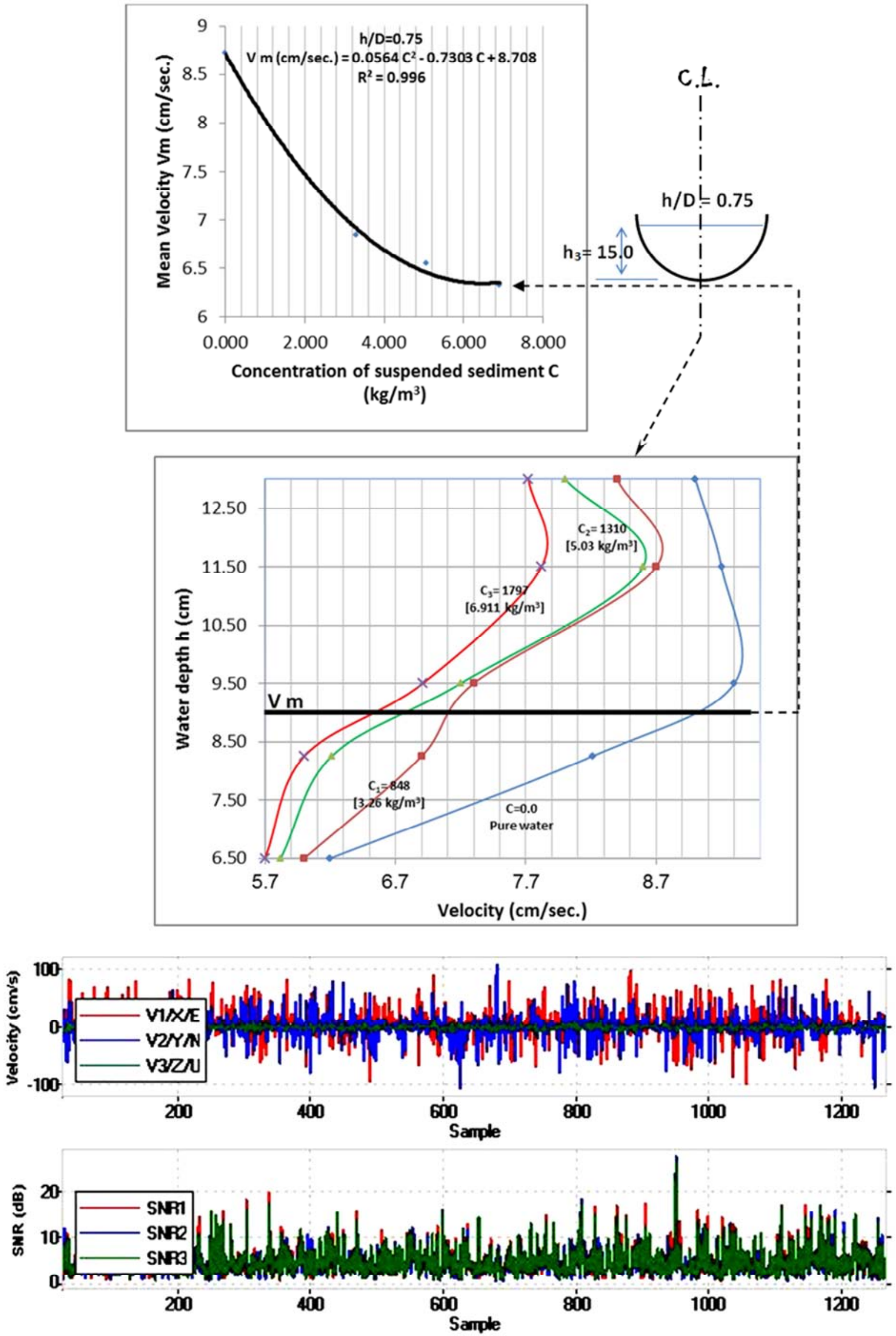

Figure 12. Velocity distribution at for final suspended load concentrations at $[h / D=0.75]$. 


\section{Sediment with Water Depth}

final bed and suspended loads.

Figure 13 shows the relationship between water depth and

From this figure, it was appeared that with the increasing of water depth, the bed load increases and consequently decreases in suspended load concentration.
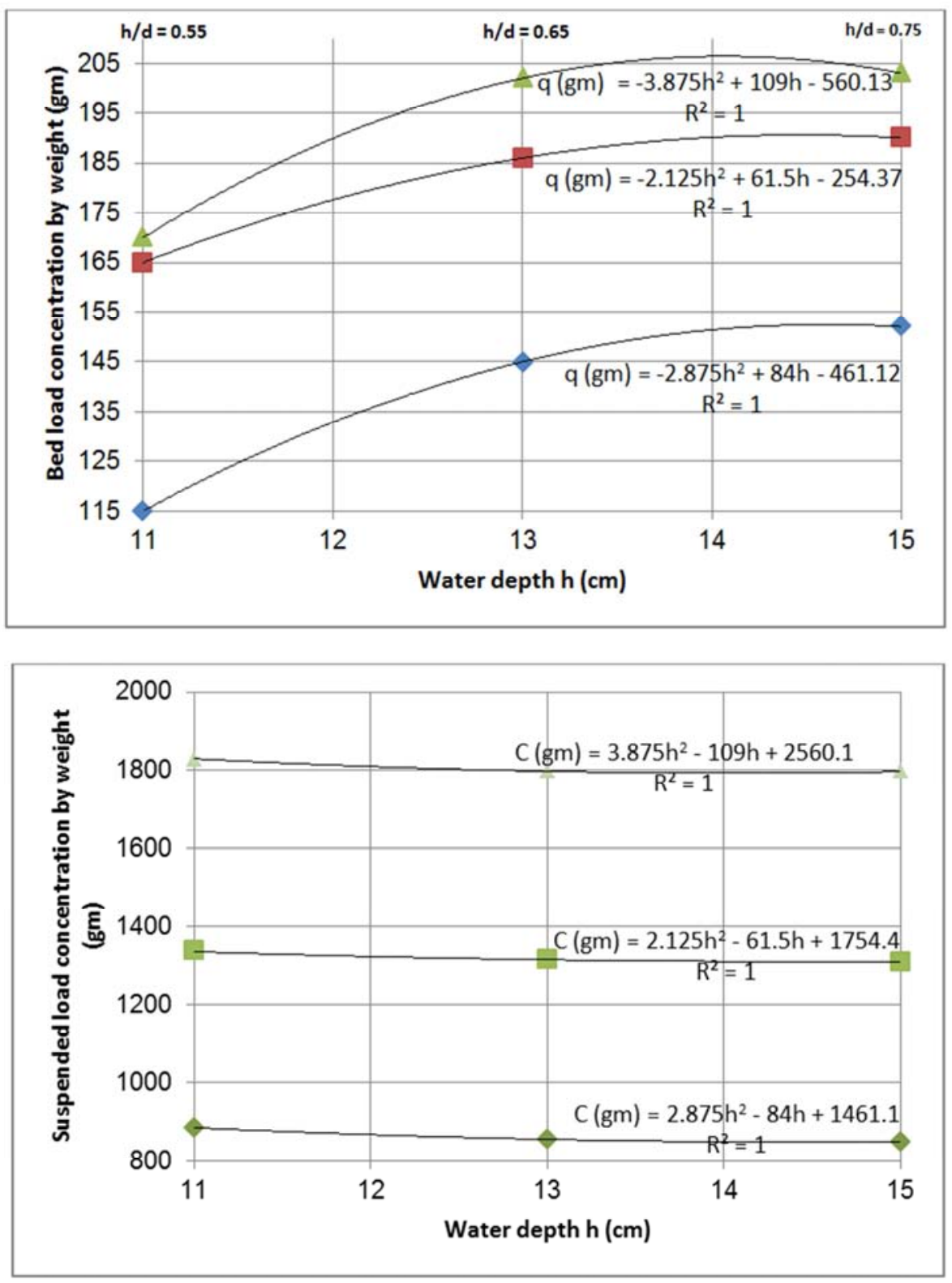

Figure 13. Relationship between bed and suspended load and water depth.

Some of velocity results for the three selected water depth-diameter ratio $(0.55,0.65$ and 0.75$)$ were given in the form of following tables.

Table 2. Velocity values at $h / D=0.55$.

\begin{tabular}{|c|c|c|c|c|}
\hline & & $\mathrm{h} 1=11 \mathrm{~cm}$ & & \\
\hline & Run 1 & Run 2 & Run 3 & Run 4 \\
\hline Sus. L. & $\mathrm{C}=0.0$ & 885 & 1335 & 1830 \\
\hline $\mathrm{h}(\mathrm{cm})$ & $\mathrm{V}(\mathrm{cm} / \mathrm{sec})$. & $\mathrm{V}(\mathrm{cm} / \mathrm{sec})$. & $\mathrm{V}(\mathrm{cm} / \mathrm{sec})$. & $\mathrm{V}(\mathrm{cm} / \mathrm{sec})$. \\
\hline 5.0 & 8.33 & 7.61 & 7.42 & 7.31 \\
\hline 7.0 & 8.92 & 8.22 & 7.91 & 7.81 \\
\hline 9.0 & 10.21 & 9.51 & 8.95 & 8.5 \\
\hline 10.0 & 9.51 & 9.42 & 9.2 & 8.5 \\
\hline $\mathrm{Vm}$ & 8.625 & 7.915 & 7.665 & 7.56 \\
\hline
\end{tabular}


Table 3. Velocity values at $h / D=0.65$.

\begin{tabular}{|c|c|c|c|c|}
\hline & & h1 $=13 \mathrm{~cm}$ & & \\
\hline & Run 5 & Run 6 & Run 7 & Run 8 \\
\hline Sus. L. & $\mathrm{C}=0.0$ & 855 & 1314 & 1798 \\
\hline $\mathrm{h}(\mathrm{cm})$ & $\mathrm{V}(\mathrm{cm} / \mathrm{sec})$. & $\mathrm{V}(\mathrm{cm} / \mathrm{sec})$. & $\mathrm{V}(\mathrm{cm} / \mathrm{sec})$. & $\mathrm{V}(\mathrm{cm} / \mathrm{sec})$. \\
\hline 5.0 & 8.03 & 7.31 & 7 & 6.8 \\
\hline 7.0 & 8.5 & 7.8 & 7.6 & 7.5 \\
\hline 9.0 & 9.88 & 8.9 & 8.5 & 8.1 \\
\hline 11.2 & 9.77 & 9.3 & 8.9 & 8.5 \\
\hline 12.0 & 9.22 & 8.9 & 8.7 & 8.6 \\
\hline $\mathrm{Vm}$ & 9.012 & 8.151 & 7.921 & 7.758 \\
\hline
\end{tabular}

Table 4. Velocity values at $h / D=0.75$.

\begin{tabular}{lllll}
\hline & & h1=15 cm & & Run 12 \\
\hline Sun. L. & Run & Run $\mathbf{1 0}$ & Run 11 & 1797 \\
$\mathrm{~h}(\mathrm{~cm})$ & $\mathrm{C}=0.0$ & 848 & 1310 & $\mathrm{~V}(\mathrm{~cm} / \mathrm{sec})$. \\
6.50 & $\mathrm{~V}(\mathrm{~cm} / \mathrm{sec})$. & $\mathrm{V}(\mathrm{cm} / \mathrm{sec})$. & $\mathrm{V}(\mathrm{cm} / \mathrm{sec})$. & 5.7 \\
8.25 & 6.2 & 6 & 5.82 & 6 \\
9.50 & 8.21 & 6.9 & 6.21 & 6.91 \\
11.50 & 9.3 & 7.3 & 7.2 & 7.82 \\
13.00 & 9.2 & 8.7 & 8.6 & 7.72 \\
$\mathrm{Vm}$ & 9 & 8.4 & 8 & 6.321 \\
\hline
\end{tabular}

\section{Conclusion}

This experimental work was carried out to study the effect of different concentrations of fine sediments on the velocity distribution in circular cross section.

- An ADV instrument was used for measuring the vertical velocity distribution at the centerline of channel.

- Three values of total loads of $1000 \mathrm{gm}, 1500 \mathrm{gm}$ and 2000 gm were added to the input upstream tank of the used channel with $0.26 \mathrm{~m}^{3}$ volume. They all fine sediments.

- A trap was designed at the end of the channel in order to find separately the final concentrations of suspended load and bed load.

- Three water depths were used $11 \mathrm{~cm}, 13 \mathrm{~cm}$ and $15 \mathrm{~cm}$ to give depth-diameter ratios of $0.55,0.65$ and 0.75 .

- The final deduced time of each run that used for separating between bed and suspended loads was three hours.

- It was concluded that, with the increasing of suspended load, the water velocity decreases obviously because the values of fall velocity will increase and consequently cause the increase in turbulent shear stress.

- The increasing of water depth with the same discharge causes the increase of bed load and consequently the decrease in the corresponding suspended load concentrations.

- Three final equations were deduced to associate between the concentration of suspended load by $\left(\mathrm{kg} / \mathrm{m}^{3}\right)$ and the mean water velocity measured by ADV instrument by $(\mathrm{cm} / \mathrm{sec}$.) for circular cross section as:

$$
\begin{aligned}
\mathrm{V}_{\mathrm{m}}(\mathrm{cm} / \mathrm{sec} .) & =0.0167 \mathrm{C}^{2}-0.2702 \mathrm{C}+8.6273 \\
\mathrm{R}^{2} & =0.9993 \mathrm{at}[\mathrm{h} / \mathrm{D}=0.55] \\
\mathrm{V}_{\mathrm{m}}(\mathrm{cm} / \mathrm{sec} .) & =0.0211 \mathrm{C}^{2}-0.3257 \mathrm{C}+9.0092 \\
\mathrm{R}^{2}= & 0.9993 \text { at }[\mathrm{h} / \mathrm{D}=0.65] \\
\mathrm{V}_{\mathrm{m}}(\mathrm{cm} / \mathrm{sec} .) & =0.0564 \mathrm{C}^{2}-0.7303 \mathrm{C}+8.708 \\
\mathrm{R}^{2}= & 0.996 \text { at }[\mathrm{h} / \mathrm{D}=0.75]
\end{aligned}
$$

\section{References}

[1] Al-Khafif S. "Study of open channels degradation and corresponding bed roughness", Ph.D. thesis, University of California, 1965.

[2] Coles D. "The law of wake in the turbulent boundary layer", Journal of Fluid Mech., Vol.1, pp. 191-226, 1956.

[3] Coleman N. "Velocity profiles with suspended sediment", Journal of Hydraulics Research, Vol. 19 (3), pp. 211-229, 1981.

[4] Einstein H. and Chien N. "Effects of heavy sediment concentration near the bed on the velocity and sediment distribution", Report. No. 8, University of California, Berkeley, CA, 1955.

[5] Grant, J., Walker, T. R., Hill P. S., Lintern, D. G. "BEAST-A portable device for quantification of erosion in intact sediment cores", Methods in Oceanography. DOI: 10.1016/j.mio.2013.03.001, 2013.

[6] Itakura T. and Kishi T. "Open channel flow with suspended sediments", Journal of Hydraulics Division, ASCE, Vol. 106 (8), pp. 1325-1343, 1980. 
[7] Lavelle J. and Thacker W. "Effects of hindered settling on sediment concentration profiles", Journal of Hydraulics Research, IAHR, Vol. 16 (4), pp. 347-355, 1978.

[8] Mazumder B. and Ghoshal K. "Velocity and concentration profiles in uniform sediment-laden flow", Applied Mathematical Modeling, Vol. 30 (2), pp. 164-176, 2006.

[9] Milad K., Kyle S. and Qin Q. "A Literature Review on the Sediment Transport Process in Shallow-Grade Culverts and Storm Sewers", Proceedings of the ASEE Gulf-Southwest Annual Conference Organized by The University of Texas at San Antonio, 2015.

[10] Newton C. "An experimental investigation of bed degradation in an open channel", Transcript, Boston Society of Civil Engineers, pp. 28-60, 1951.

[11] Nezu I. and Rodi W. "Open-channel flow measurements with a Laser Doppler Anemometer", Journal of Hydraulics Engineering, ASCE, Vol. 112, pp. 335-355, 1986.
[12] Nezu I. and Nakagawa H. "Turbulence in open-channel flows", IAHR Monograph A. A. Balkema Publishers, Rotterdam, 1993.

[13] Pellachini I. "Modeling fine sediment transport over an immobile gravel bed", Trento: Unitn - eprints. 2011.

[14] Schlichting H. and Gersten K. "Boundary layer theory", (8th ed.) Springer, 2000.

[15] Suryanarayana B. and Shen W. "Laboratory study of degradation and aggradation", Journal of Waterways, Harbors and Coastal Engineering Division, Vol. 97, pp.615-630, 1971.

[16] Woo H., Julien P. and Richardson E. "Suspension of large concentration of sands", Journal of Hydraulics Engineering, ASCE, Vol. 114, pp. 888-898, 1988.

[17] Vanoni V. "Transportation of suspended sediment by water", Trans. ASCE, Vol. 111, pp. 67-133, 1946. 